\title{
Production of fish protein hydrolysate from silver catfish (Arius thalassinus)
}

\begin{abstract}
Fish protein hydrolysates are broken-down products of enzymatic conversion of fish proteins into smaller peptides, which normally include 2-20amino acids. In recent years, fish protein hydrolysates have attracted much attention of food technologists due to the availability of ample quantities of raw material for the process and presence of high protein content with good amino acid balance, minerals as well as vitamins. In the present study, fish protein hydrolysate was produced for human consumption using papain enzyme from plant origin optimally achieved at neutral $\mathrm{pH}$.

Catfish (Arius thalassinus) a low-value fish from Eritrean Red Sea waters was used as substrate. The process consisted of dressing, separation of flesh by boiling and hand picking, washing the flesh, separating the dark flesh from bones, enzymatic digestion, deactivation of enzyme, drying and powdering. Under optimal condition, hydrolysis of protein by enzymes yielded products containing coagulable nitrogen, proteases, peptones, sub-peptones and free amino acid depending on the extent of degradation of proteins which is related to the type, concentration of enzyme and condition of hydrolysis (temperature and time). The product was high in protein $(80-85 \%)$ and ash $(5.2 \%)$ contents and low in fat $(0.5 \%)$, and moisture content $(6.8 \%)$. Solubility of the Fish protein hydrolysate was investigated using water and found soluble in water, which makes it an alternative protein supplement for undernourished population. The product was tested in a beverage form by taste panelists for its acceptability and was acceptable to $80 \%$ by the respondents.
\end{abstract}

Keywords: catfish (arius thalassinus), proximate composition, fish protein hydrolysate, papainwidth of diffraction lines, crystalline network constant
Volume 5 Issue 4 - 2017

\author{
Bereket Abraha, ${ }^{1,2}$ Abdu Mahmmud, ${ }^{1,2}$ Melake \\ Samue, ${ }^{1,2}$ Weyni Yhdego, ${ }^{2}$ Selamawit Kibrom, ${ }^{2}$ \\ Weldemariam Habtom ${ }^{2}$ \\ 'School of Food Science and Technology, Jiangnan University, \\ China \\ ${ }^{2}$ Department of Marine Food and Biotechnology, Massawa \\ College of Marine Science and Technology, China
}

\begin{abstract}
Correspondence: Bereket Abraha, School of Food science and Technology, Jiangnan University, Wuxi 214122, China, Tel +86|86-1667226, Fax +86-5 |0-858096 |0,
\end{abstract}

Email bereketmft@yahoo.com

Received: October 09, 2017 | Published: December 14, 2017

\section{Introduction}

Fish are highly nutritious food items. In most countries, fish is one of the significant sources of animal protein and essential nutrients for the maintenance of health and protection from different types of diseases, such as blood pressure, cancer and heart stroke. ${ }^{1}$ Sea food products reduce vulnerability to hunger by providing a complementary food source when other food sources, such as agriculture are at a seasonal low. ${ }^{2}$ Foran et $a .^{3}$ stated in the findings, fish is a highly proteinaceous food consumed by a larger percentage of population in the world because of its availability and palatability. Today there is an ever increasing know-how about healthy food and fish is finding more acceptances because of its special biochemical and nutritional qualities. ${ }^{4}$

In most of the developing countries, or the so called emerging countries, Eritrea being one of them, there have not been such significant advances in health of the population. The result is a wide spread malnutrition, particularly protein malnutrition for the vulnerable population especially children, pregnant mothers etc. Likewise, the exploration of population in these countries, global climate changes have greatly reduced the proportion of agricultural land and besides lack of skilled manpower and inputs in fisheries sector have contributed to low outputs of fish capture, that could provide vitally needed animal proteins. ${ }^{5}$ Abraha et al..$^{5}$ and ${ }^{6}$ reported, Eritrea's coastal waters are among the most productive fishing grounds in the Red Sea. The existing fish population of large and small pelagic fishes includes: tuna, queen fish, catfish, mackerel, barracuda, shark, grouper, anchovies, sardine etc. The Maximum Sustainable Yield of marine fish resource of Eritrean Red Sea is estimated 80,000 metric tons per year. Sliver catfish, Arius thalassinus, are abundantly found in the Dahlak Archipelago Islands of Eritrean Read Sea waters. Catfish are among the low values fishes which have very low consumption rate compared to coral reef fishes. Moreover, this species has poor acceptance in the consumer market..$^{5,7}$ These are underutilized resources of fish, that man could turn them to sources of animal protein in an enormous quantity at low cost. ${ }^{2}$ What is needed is to develop a method of using fish as high quality protein supplement to upgrade lower quality vegetable proteins, which are presently the main source of this important nutrient. The product produced from fish must be easy to store, distribute and retail at ambient temperatures to enable to reach the remote areas of the country and yet retaining its high nutritional value. The product produced must be available in a form to be introduced in to a wide variety of traditional meals to ensure that it can enhance to increase nutritional content diets of the people, moreover the targeted consumers. Fish Protein Hydrolysate (FPH) is the best example of these, prepared by concentrating fish proteins. Catfish hydrolysates powder has high protein content due to the solubility of protein during hydrolysis; removal of insoluble and undigested non protein substances; and partial removal of lipid after hydrolysis. ${ }^{8}$

Preparation of fish protein hydrolysate (FPH) using low value fish and fish wastes to achieve better utilization of fish, have received the attention of researchers for the last five to six decades. ${ }^{9,10}$ Patents on preparation of peptones and amino acids were taken in early 1950's in Japan and U.S. Work on fish protein hydrolysate was initiated in India in early 1960 's at the central food technological research station. ${ }^{11}$ 
In addition to over exploitation and wastage of protein rich food, more than $50 \%$ of fish is considered as inedible or processing wastes comprising of head, skin, bone, scales, fins and viscera which are not utilized for food and mostly used as animal feed. ${ }^{4}$ In recent years, strict environmental regulations are no longer allowing processing companies to discard wastes. Therefore there is an urgent need to eliminate by-catch by designing efficient gears, control post-harvest fish losses and develop alternative methods for better and complete utilization of fish. ${ }^{2}$

FPH are prepared by treating fish or fish waste with proteases, the soluble fraction is concentrated to get powdered protein hydrolysates which has better functional and nutritive properties as well as high solubility in water compared to fish protein concentrate. ${ }^{12,13}$ By using different fish species, enzymes and digestion conditions, a wide range of hydrolysates can be developed. ${ }^{4}$ The enzymes can be of plant (papain, bromelin, ficin), animal (pepsin, trypsin etc.), or microbial (pronase, alcalase, etc.) origin. ${ }^{2}$ By careful control of hydrolysis, it is possible to modify the functional properties such as water holding capacity, emulsifying and foaming ability of proteins. The degree of hydrolysis is important to optimize the process parameters to get a high quality product. ${ }^{4,14}$

Protein hydrolysates are generally used for modification of functional properties of foods and use of low cost raw material content of high quality proteins. The high solubility property of the hydrolysates also adds to their features of being an ideal protein supplement to vulnerable population of developing and developed countries. ${ }^{2,15}$ Production of fish protein hydrolysate could be the best option to upgrade low value fish such as silver catfish, thereby increasing their consumer acceptability and ultimately improve their consumption rate. This study was, therefore, undertaken to produce and evaluate acceptability of fish protein hydrolysate prepared from underutilized low value silver catfish from Eritrean Red Sea. Pre-school children and pregnant/nursing mothers are the most beneficiaries of the high nutritional values of this product.

\section{Materials and methods}

\section{Study location}

The study was conducted at the Marine Biotechnology laboratory, in Massawa College of Marine Science and Technology, Eritrea.

\section{Materials used}

The experimental fish was silver catfish (Arius thalassinus), ${ }^{16}$ caught around Dahlak Archipelago Islands of Eritrean Red Sea waters by gill net and kept in fish boxes using ice and transported to the laboratory of Massawa College of Marine Science and Technology. Rough balance of $5 \mathrm{Kg}$ capacity $/ 0.25 \mathrm{~g}$ and fine balance of $300 \mathrm{~g}$ capacity $/ 0.1 \mathrm{~g}$ were used for weighing enzyme, flesh and dried powder products. A thermostatically controlled vacuum oven drier type VP-3, $\mathrm{No}=5505$ having $40-220^{\circ} \mathrm{C}$ capacity, was used for drying the product. A digital thermometer with a range between $-50-300^{\circ} \mathrm{C}$ (LCD portable multi-system thermometer; No. 201211253516 Hutaib Enterprise, India) was used for measuring temperature at various stages. Boiling bath with serial $\mathrm{No}=56638$, made up of nickel electron LTD with working capacity of $1-100^{\circ} \mathrm{C}$ was used for the temperature controlled liquefaction or hydrolysis process. Dishes and white cloth mesh were used for boiling process and squeezing process.

\section{Methodology}

Preparation of protein hydrolysate: The hydrolysis was carried out as describe by Adler-Nissen. ${ }^{14}$ A $5 \mathrm{Kg}$ of silver cat fish (Arius thalassinus) preserved in ice was used in preparation of the protein hydrolysate. Fish sample was organoleptically of sound quality having uniform appearance, maturity and size. It was handpicked from the lot and used for the study. The procedure followed for the preparation of FPH is given in the flow diagram (Figure 1).

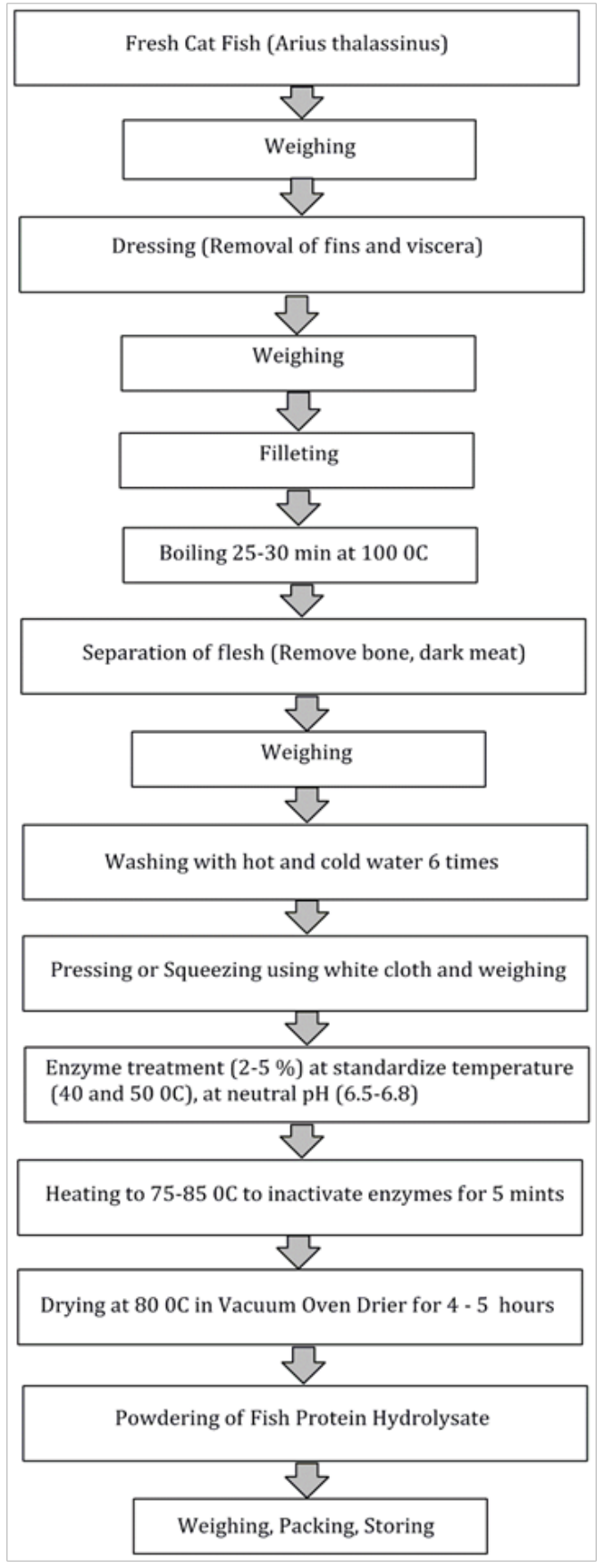

Figure I Flow diagram of fish protein hydrolysate. 
Initially, the fish was weighed, washed with clean water and dressed to remove the waste parts. The dressed fish was then again washed by clean water to remove some of the dirt remains and then cooked and left to cool. Following the cooking and cooling process, the bones and dark meat were separated manually. The separated flesh was then washed repeatedly with cold and hot water, to reduce fat. The flesh was pressed using a white cloth mesh to remove water and was ground in to small pieces. Then, the flesh was mixed with required amount of enzyme and subjected to hydrolysis for a specified time at particular temperature. After hydrolysis the samples were heated at $75-800^{\circ} \mathrm{C}$, to inactivate the enzyme and were subjected to oven drying. The dried samples were blended to produce powder and sieved to get a fine powder. Finally the samples were packed in polythene bags and heat sealed.

Measuring the degree of hydrolysis: The degree of hydrolysis with time and temperature was monitored by the method described. ${ }^{17}$ Degree of hydrolysis of FPH was measured by taking two different temperatures $\left(45\right.$ and $\left.500^{\circ} \mathrm{C}\right)$ and four different enzyme concentrations $(2 \%, 3 \%, 4 \%$ and $5 \%)$ in triplicate samples were analyzed per each enzyme concentration and at different temperatures. The number of samples were 24 batches, each contain $40 \mathrm{~g}$. All batches were treated with known concentration of enzyme. Boiling of samples was done sequentially; and rate of hydrolysis were measured at time interval of 3 minutes.

Proximate composition: The proximate analyses on crude protein, crude fat, ash and moisture were carried out in the fresh fish. The analyses were done according the method of Association of Official Analytical Chemistry (AOAC). ${ }^{18}$ The following parameters were measured: crude protein (Kjeldahl method), ash (muffle furnace), crude fat (Soxhlet method), moisture content (thermostatically controlled forced air oven, $105^{\circ} \mathrm{C}$ for 8 hours).

Determination of crude protein: Protein content in the sample was estimated using Micro- Kjeldhal method. Estimation was done in Asmara national laboratory and the principle they follow was kjeldhal method, involves digestion, distillation and titration. FPH samples (1g) were taken in the digestion tube, to this anhydrous potassium sulphate was added to increase boiling point, and copper sulphate was added as a catalyst or to speed up the reaction, concentrated sulphuric acid was added as oxidizing agent. The material was left over night to enhance digestion and then the material was digested in the digestion blocks at the temperature of $420^{\circ} \mathrm{C}$, this process is called digestion. The sample was distilled by passing steam, ammonia liberated due to addition of alkali and trapped in boric acid. Boric acid in $\mathrm{NH}_{3}$ was titrating against the standardized hydrochloric acid using methyl red indicator. The percent nitrogen is calculated using the titer value. The protein content was obtained by multiplying the percent of nitrogen with the factor 6.25 .

$$
N(\%)=\frac{(V 1-V 2) * \text { normality } * 14.01 * 100 \%}{w * 1000}
$$

Where,

$\mathrm{V} 1=$ volume of $\mathrm{H}_{2} \mathrm{SO}_{4}, \mathrm{ml}$

$\mathrm{V} 2=$ volume of blank, $\mathrm{ml}$

\section{$\mathrm{W}=$ weigh of sample, $\mathrm{g}$}

$\mathrm{N}=$ Nitrogen, \%

\section{Protein content $=\mathrm{N} \% \times 6.25$}

Determination of crude fat: Crude fat content was determined using Soxhlet solvent extraction method. ${ }^{18}$ Petroleum ether a non polar solvent was used for the extraction of crude fat from sample. Sample was placed in the thimble porous material. Petroleum ether was placed in distillation flask and heat was given as a result, solvent was vaporized and condensed on the upper part then cooled and drops to the thimble, then the solvent washed out to the fat present on the food. This process was done continuously for a period of one hour until all the fat present was finished. At the end of experiment solvent was allowed to vaporize. The flask was reweighed along with the fat present in the food by subtracting weight of empty distillation flask from the reweighed weight it can be calculate the amount of fat present in the food.

$$
\text { Fat }(\%)=\frac{(\text { Weightofflask }+ \text { fat })-\text { Weightofemptyflask }}{\text { Weightofsample }} * 100
$$

Moisture content: Residual moisture was determined gravimetrically by heating the sample at $105^{\circ} \mathrm{C}$ for 8 hours in hot air drying oven until a constant weight has achieved. The moisture content was stated as percentage by dry weight of sample. ${ }^{18}$

Ash content: Ash content of the sample was determined according to the method of Association of Official Analytical Chemistry. ${ }^{18}$ Ash content was determined by complete igniting of the sample (4-6gram) in a muffle furnace at a temperature of $550^{\circ} \mathrm{C}$ for 6 hours and ash was calculated in percentage as:

$$
\operatorname{Ash}(\%)=\frac{(\text { Weightofcrucible }+ \text { ash })-\text { Weightofemptycrucible }}{\text { Weightofsample }} * 100
$$

\section{Sensory evaluation}

Test for acceptability: The consumer's acceptability of the product was evaluated by a group of 30panelists using the nine point Hedonic rating scale according the method described. ${ }^{19}$ The panelists were randomly selected from the department of Marine Food and Biotechnology and Eri-Fish processing plant. Hedonic scale was in the following sequence: $9=$ Like extremely, $8=$ Like very much, $7=$ Like moderately, $6=$ Like slightly, 5=Neither like nor dislike, 4=Dislike slightly, $3=$ Dislike moderately, $2=$ Dislike very much and $1=$ Dislike extremely.

Statistical analysis: The statistical analyses were performed using statistical program (SPSS 18.0) for Windows. All analytical determinations were performed in triplicate and the mean values were reported. The result of hydrolysis with reference to variation in enzyme concentration and temperature were statistically analyzed using two-way ANOVA as describe. ${ }^{20}$ Difference between mean were reported at a significant level, $\mathrm{p} \leq 0.05$. Descriptive analyses were also used in organoleptic analysis for the acceptability. 


\section{Results and discussion}

\section{Proximate composition and weight composition of raw material fish}

Size and weight of a fish is very important in the yield of fish protein hydrolysate. The average weight of the samples used in this study was 3.85 to $5 \mathrm{~kg}$. The data represented at Table 1 are proximate composition of the raw material used in the present study. The proximate composition of silver cat fish was $18.56 \%$ crude protein, $0.54 \%$ fat, $79.15 \%$ moisture and $1.75 \%$ ash content. The results of the present study are in agreement with earlier findings, ${ }^{21}$ who studied Proximate Composition and Technological Properties of Wild African Catfish Chrysichthy snigrodigitatus (Lacépède1802).

The weight composition is the contribution of each part of fish to the total weight expressed as percentage. The cat fish sample used in this study constituted of $43-49 \%$ edible flesh. The inedible part such as head, gill and skeleton constituted major part of the waste (Table 2), which is in accordance with the result found by $\mathrm{Hsu} .{ }^{22}$ The variation in weight composition due to the size and shape of the fish depends on the skill of filleting. This variation within the species appears to be very significant and can be attributed to the difference in size of fish as bigger fish yield higher edible portions.

\section{Production data}

The yield of FPH from whole cat fish (Arius thalassinus) was found to be $(7 \%$ and $6.9 \%)$ as shown in table 3. The yield of flesh was $49 \%$ and $43 \%$ (Table 2). In most of fishes the 21 ratio of edible to inedible part is 50:50. In the production of FPH, substantial amount of wastes were generated which needs to be efficiently utilized. Thankamma et al. ${ }^{23}$ have reported a yield of $10.9 \%$ from whole catfish (Arius tachysurus) and 7.8\% from jaw fish (Johnius spp.). The yield is comparatively less in the present study ( $7 \%$ and $6.9 \%)$. This may be due to variation of weight composition and proximate composition especially moisture and fat content which show wide variation in fish. ${ }^{24}$

\section{Processing details}

Fish flesh preparation: For production of FPH raw flesh/minced meat or cooked flesh can be used. In large scale production it is not economical to cook and separate by hand, therefore use of raw minced meat is practical. In the present experiment the dressed fish (catfish) were cooked, pressed and washed. The cooking and pressing operation resulted in a light color flesh. The yield after cooking from separated flesh was $26.31 \%$ in sample 1 and $26.08 \%$ in sample 2 respectively. Cooking softened the flesh, resulting in breakage of the muscle tissue and partially reduced fat content of $0.728 \%$ and $1.604 \%$ in Samples 1 and 2 respectively (Table 3 ). The process has also facilitated easy separation of bone and dark meat, as well as coagulation of proteins. Similar observations were recorded by Sngiyama et al. ${ }^{25}$ applied on defatted sardine (Sardinella longiceps) and Normah et al. ${ }^{26}$ in threadfin bream (Nemipterus japonicas). Further washing followed by manual cloth mesh pressing, played a major role in reducing the fat content in addition to the removal of water soluble protein. This is because fat content in flesh is very sensitive to auto-oxidation, tracer of fat may cause flavor reversion during storage.

Enzyme concentration: In the present study papain was used at various concentration $2 \%, 3 \%, 4 \%$ and $5 \%$ to standardize with optimum level (Table 4) following the method described by Sen et al. ${ }^{27}$ Enzymes such as papain, has been widely used for hydrolysis of fish protein compared to acid hydrolysis. It was found that 3\% papain at $50^{\circ} \mathrm{C}$ was optimum for the preparation of $\mathrm{FPH}$, which is supported by Bhaskar et al. ${ }^{28}$ The results of the study were slightly lower than a study conducted by Wisuthiphaet et al. ${ }^{2}$ who found $6 \%$ at $62.23^{\circ} \mathrm{C}$ as optimal condition for hydrolyzing of fish protein.

Temperature of hydrolysis: On the basis of degree of hydrolysis Sripathy et al. ${ }^{29}$ suggested that temperature and enzyme concentration play an important role in release of essential amino acid. In the present study, it was found that increasing enzyme concentration and temperature have a little positive impact and gave a bitter taste on the final product, so a standardized of $3 \%$ enzyme concentration, at $45-50^{\circ} \mathrm{C}$ for one hour duration was optimum (Table 5) (Figure 2). The criterion for the duration of hydrolysis is the solubilization of protein material which was tested during liquefaction by dissolving the hydrolyzed material in water. This signifies that, in incorporating FPH with beverages, solubility is the important factor with respect to temperature. Complete solubilization was considered as optimum degree of hydrolysis. Wisuthiphaet et al. ${ }^{2}$ stated in their findings that period of hydrolysis could be decided based on the end use of product.

Statistical analysis: The effect of temperature and enzyme on degree of hydrolysis of myofibrillar protein with papain enzyme is given (Table 5) (Figure 2). Degree of hydrolysis is affected by time, temperature, enzyme concentration and environmental factors like $\mathrm{pH} .{ }^{30}$ Degree of hydrolysis differed ( $\mathrm{p}$ value $<0.05$ ) depending on the use of papain and reaction time, myofibrillar protein showed higher rate of hydrolysis when treated with $5 \%$ papain. The rate of enzymatic hydrolysis increases as enzyme concentration increases. ${ }^{2}$ Lower enzymatic hydrolysis $2 \%$ takes longer time compared to $5 \%$ (Tables 4) (Table 5). At higher temperature $\left(50^{\circ} \mathrm{C}\right)$, hydrolysis rate was significantly different from $45^{\circ} \mathrm{C}$ with respect time and higher enzyme concentration was significantly different from lower concentration $2 \%$ with respect to temperature $\left(45\right.$ or $\left.50^{\circ} \mathrm{C}\right)$. Over all hydrolysis rate at $45^{\circ} \mathrm{C}$ and $50^{\circ} \mathrm{C}$ was significantly different (Table 2). Degree of hydrolysis was measured depending on the solubility. According to this study, the readily solubilized protein without any residues shows the degradation of protein to simple form. Study on degree of hydrolysis by Sugiyama et al. ${ }^{25}$ reported that, the peptide content of myofibrillar protein and its hydrolysate were significantly increased with the increase in time incubation $(\mathrm{p}$ value $<0.5$ ) from 85.5 to $299.1 \mathrm{mg} / \mathrm{g}$ estimating alpha-amino nitrogen content.

Proximate composition: The chemical composition of fish and fish protein hydrolysates has an essential role on human health to provide the essential nutrients in order maintain good health. Generally proximate composition of fish protein hydrolysate varies with type of fish, and enzyme used. In the present study, the proximate analyses of the experimental fish were: crude protein content range (81.8-93.1), moisture content (1.4-8.5), ash content (3.2-8.6) and fat content (0.0$5)$. The high protein content of fish protein hydrolysates obtained in these findings elucidate its potential use as protein supplements for human nutrition specially to children, pregnant women and immune suppressed people. FPH had low moisture content which is related to high temperature employed during processing and drying which has vital role in extending the shelf-life of the product. ${ }^{31,32}$ This result is in agreement with Martone et al. ${ }^{33}$ who prepared highly soluble fish protein hydrolysates with $80 \%$ protein from hake (Merluccius hubssi). According to Nair et al. ${ }^{24}$ proximate compositions of FPH from whole fish of thread fin were found: protein $86.4 \%$, fat $0.1 \%$, ash $7.6 \%$ and 
moisture 3.5\%. The FPH from catfish prepared in the present study showed similar results (Table 6) (Figure 3). Higher fat content of FPH compared to previous studies may be due to incomplete removal of fat. Sincefish fat is rich in poly unsaturated fatty acids and is susceptible to auto oxidation, extreme care is required during defatting. ${ }^{8,33}$

Consumer acceptability of FPH: The overall acceptability of beverage prepared from FPH on a nine point hedonic scale indicated

Table I Proximate composition of raw material fish that the product is acceptable to $80 \%$ of the respondents. Comparing "like" to "dislike" percentage responses, FPH was acceptable as shown in the Figure 4. Earlier study reported that fish protein hydrolysate has a problem with bitterness. ${ }^{10}$ However, in this study the FPH was received best acceptance and very liked by the panelists and the overall acceptability was about $80 \%$ out of 30panelists.

\begin{tabular}{ll}
\hline Proximate Composition & \% Wet basis \\
\hline Crude protein & 18.56 \\
Fat & 0.54 \\
Moisture & 79.15 \\
Ash & 1.75 \\
\hline
\end{tabular}

Table 2 Weight composition of silver cat fish (Samples I and 2)

\begin{tabular}{lllll}
\hline \multirow{2}{*}{ Parts } & \multicolumn{3}{l}{ Sample1 } & \multicolumn{2}{l}{ Sample 2 } \\
\cline { 2 - 5 } & Weight composition & \% Composition & Weight composition & \% Composition \\
\hline Flesh & $1.400 \mathrm{~kg}$ & 49.12 & $1.600 \mathrm{~kg}$ & $43.54 \%$ \\
Head, gill, skeleton & $0.875 \mathrm{~kg}$ & 30.72 & $1.350 \mathrm{~kg}$ & $36.73 \%$ \\
Viscera & $0.250 \mathrm{~kg}$ & 8.77 & $0.350 \mathrm{~kg}$ & $9.53 \%$ \\
Airbladder & $0.050 \mathrm{~kg}$ & 1.75 & $0.060 \mathrm{~kg}$ & $1.63 \%$ \\
Fins & $0.125 \mathrm{~kg}$ & 4.38 & $0.150 \mathrm{~kg}$ & $4.08 \%$ \\
Skin & $0.150 \mathrm{~kg}$ & 5.26 & $0.165 \mathrm{~kg}$ & $4.49 \%$ \\
\hline
\end{tabular}

Table 3 Yield of fish protein hydrolysate $(\mathrm{kg})$ from the two cat fish samples

\begin{tabular}{llllllll}
\hline \multirow{2}{*}{ Cat Fish } & \multicolumn{7}{l}{ Product yield in kg } \\
\cline { 2 - 8 } & Initial fish wt. & Flesh & After boiling & After squeezing & After hydrolysis & After drying & Final powder \\
\hline Sample No. 1 & 2.85 & 1.35 & 1 & 0.75 & 0.6 & 0.35 & 0.2 \\
Sample No. 2 & 3.68 & 1.6 & 1.28 & 0.96 & 0.768 & 0.448 & 0.256 \\
\hline
\end{tabular}

Table 4 Duration of hydrolysis (min) versus enzyme concentration (\%)

\begin{tabular}{|c|c|c|c|c|c|}
\hline \multicolumn{6}{|c|}{ Time taken for hydrolysis (min) } \\
\hline & \multicolumn{5}{|c|}{ Percent concentration of papain enzyme added } \\
\hline & & $2 \%$ & $3 \%$ & $4 \%$ & $5 \%$ \\
\hline \multirow[t]{3}{*}{ Experiment No. 1 at $50^{\circ} \mathrm{C}$} & Replica 1 of 1 & 125 & 70 & 40 & 40 \\
\hline & Replica 2 of 1 & 131 & 66 & 40 & 34 \\
\hline & Replica 3 of 1 & 101 & 60 & 32 & 34 \\
\hline \multirow[t]{3}{*}{ Experiment No. 2 at $45^{\circ} \mathrm{C}$} & Replica 1 of 2 & 156 & 101 & 53 & 41 \\
\hline & Replica 2 of 2 & 145 & 100 & 53 & 45 \\
\hline & Replica 3 of 2 & 154 & 105 & 56 & 42 \\
\hline
\end{tabular}


Table 5 Statistical result of mean time $(\mathrm{min})$ taken at different enzyme concentration and temperature during hydrolysis

\begin{tabular}{llll}
\hline Temperature & Percent concentration of enzyme & Mean time (min) & Std. Deviation \\
\hline \multirow{3}{*}{$500^{\circ} \mathrm{C}$} & $2 \%$ & 119 & \pm 15.87 \\
& $3 \%$ & 65.33 & \pm 5.03 \\
& $4 \%$ & 37.33 & \pm 4.62 \\
& $5 \%$ & 36 & \pm 3.46 \\
& Total & 64.42 & \pm 35.91 \\
& $2 \%$ & 151.67 & \pm 5.86 \\
$450^{\circ} \mathrm{C}$ & $3 \%$ & 102 & \pm 2.65 \\
& $4 \%$ & 54 & \pm 1.73 \\
& $5 \%$ & 42.67 & \pm 2.08 \\
& Total & 87.58 & \pm 45.20 \\
\hline
\end{tabular}

Table 6 Proximate composition of fish protein hydrolysate

\begin{tabular}{lllll}
\hline & \multicolumn{4}{l}{ Chemical constituents of the fish protein hydrolysate } \\
\cline { 2 - 5 } & Protein (\%) & Fat (\%) & Ash (\%) & Moisture (\%) \\
\hline Experiment No. 1 & 87.2 & 0.728 & 5.22 & 6.85 \\
Experiment No. 2 & 85.42 & 1.604 & 4.89 & 8.09 \\
\hline
\end{tabular}

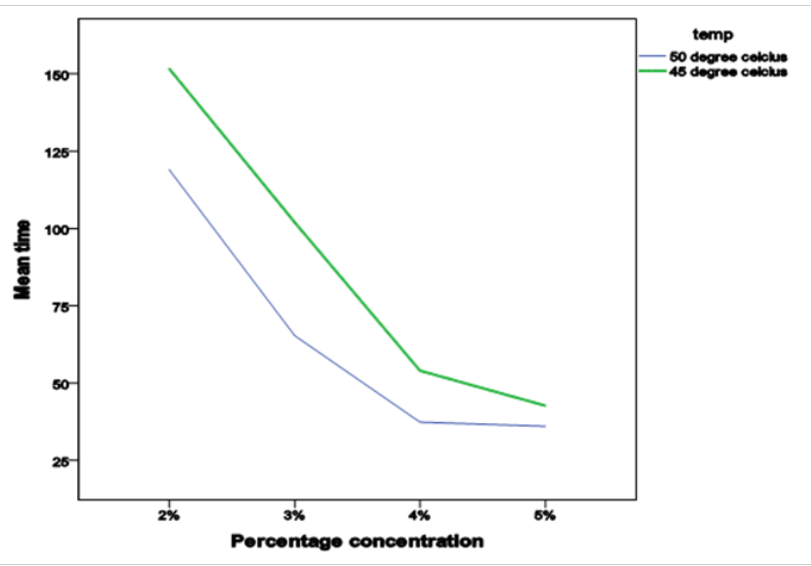

Figure2 Effect of enzyme concentration (\%) with time (min) at different temperature.

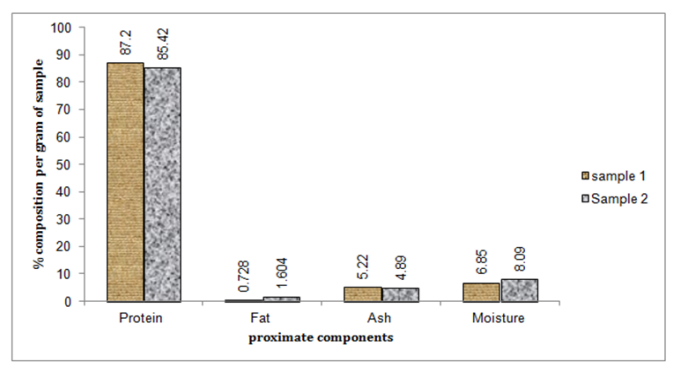

Figure 3 Graphical presentation of proximate composition for fish protein hydrolysate prepared from silver catfish.

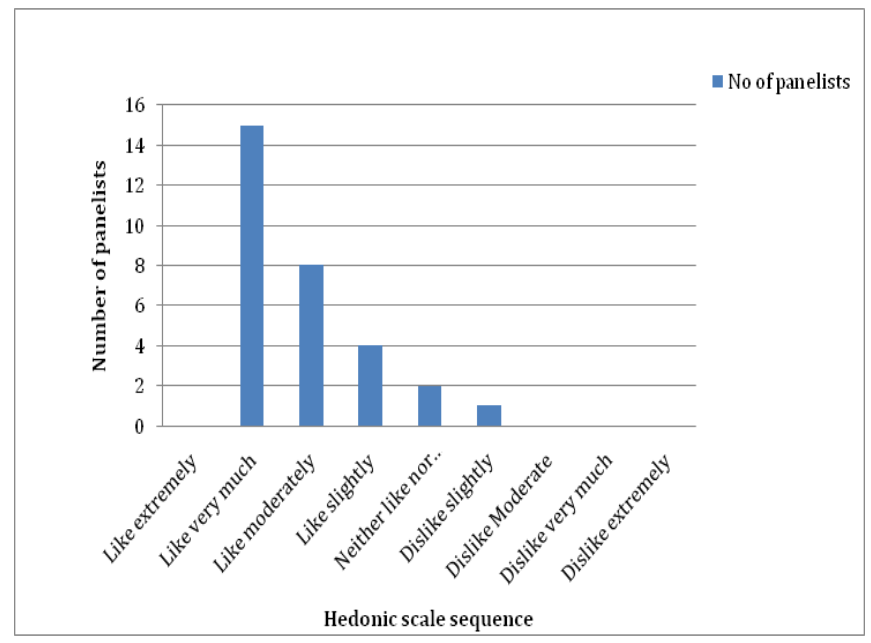

Figure 4 Acceptability of the FPH incorporated in a beverage.

\section{Conclusion}

Fish protein hydrolysate is a rich resource of protein $(\geq 85 \%)$ or amino acids which can be used for human consumption; it may also be used as constituent of growth media for industrial fermentation process. The market for such products seems to increases as a result of biotechnological research. The important questions in the use of FPH are the variation in molecular weight of different peptides and amino acids sequence and control of product quality. The type of enzyme and processing condition during hydrolysis are critical to achieve a uniform degree of hydrolysis. The therapeutic and health promoting properties 
of FPH makes them a 'Neutraceutical' with promising future. The technology preparation of FPH can be used effectively to upgrade and utilize underutilized fishes such as catfish and other varieties. In the preparation it is critical to select a cheap source of enzyme such as papain produced from papaya latex and easily available. Papain is also the enzyme chooses, because its optimal active at neutral $\mathrm{pH}$. Hydrolysis from other enzymes will be more expensive. Generally enzyme hydrolysis does not destruct amino acids compare with acids and alkaline hydrolysis.

The temperature, $\mathrm{pH}$ duration of hydrolysis needs to be controlled in order to get a uniformly hydrolyzed product. In the present study, FPH was prepared from low value silver catfish at different enzyme concentration and different temperature, standardized with the optimum level of enzyme $(3 \%)$ and temperature $\left(50^{\circ} \mathrm{C}\right)$ with one hour. With further study, the production of fish protein hydrolysates by papain enzyme could be economically suitable and profitable for industrial application, whereby to alleviate malnutrition and increase consumption rate of low value fish.

\section{Acknowledgements}

The authors are grateful to the Massawa College of Marine Science and Technology for financially supporting the research project. The authors also would like to thank Dr. Zekeria Abdulkerim, Dean of the college, Asst. Professor N.S. Sudhakara, Asst. Professor Pasience Magoha, Mr. Negasi Tsighe (Head department of Marine Food and Biotechnology), laboratory team of Eritrea Standards Institute for their technical support, encouragement and assistance.

\section{Conflict of interest}

The author declares no conflict of interest.

\section{References}

1. Fawole OO, Ogundiran MA, Ayandiran TA, et al. Mineral composition in some selected fresh water fishes in Nigeria. J Food Safety. 2007;9:52-55.

2. Wisuthiphaet N, KlinchanS, Kongruang S. Fish protein hydrolysate production by acid and enzymatic hydrolysis. KUMTNB Int J Appl Sci Technol. 2016;9(4):261-270.

3. Foran JA, Carpenter DO, Hamilton MC, et al. Risk based consumption advice for farmed Atlantic and wild pacific salmon contaminated with dioxins and dioxin like compounds. Environ Health Perspect. 2005;113(5):552-556.

4. Wisuthiphaet N, Kongruang S. Production of fish protein hydrolysates by acid and enzymatic hydrolysis. Journal of Medical and Bioengineering. 2015;4(6):466-470.

5. Abraha B, Samuel M, Mahmud A, et al. A Comparative Study on Quality of Dried Anchovy (Stelophorusheterolobus) Using Open Sun Rack and Solar Tent Drying Methods. Turkish Journal of Fisheries and Aquatic Sciences. 2017;17:1107-1115.

6. IFAD. Project Design Report (Report N0. 2294 ER), Fisher Development Project, Eastern and Southern Africa Division Programme Management Department. Asmara, Eritrea, East Africa; 2010. p. 1-94.

7. Araya TM, Krishnan M. Performance, Potential and Prospects of Fisheries Sector in Eritrea. India: IIFET Tanzania Proceedings; 2012. p. 1-6.

8. Amiza MA, NurulAshikin S, Faazaz A L. Optimization of enzymatic protein hydrolysis from silver catfish (Pangasius $s p$.) frame. International Food Research Journal. 2011;18:775-781.
9. Oosterveer P. Governing global fish provisioning: Ownership andmanagement of marine resources. Ocean \& Coastal Management. 2008;51:797-805

10. Aristotelis T Himonides, Anthony KD Taylor, Anne j morris. a study of the enzymatic hydrolysis of fish frames using model systems. Food and Nutrition Sciences. 2011;2(6):575-585.

11. Sen DP. Advances in fish processing technology. New Delhi, India: Allied publisher; 2005. $305 \mathrm{p}$.

12. Shahidi F, Han XQ, Synowiecki J. Production and characteristics of protein hydrolysates from capelin (Mallotusvillosus). Food Chemistry. 1995;53(3):285-293.

13. Venagopal V. Production of fish protein hydrolysates by microorganisms. In: Martin AM, et al. editors. Fisheries processing. Biotechnological applications, New York, USA: Springer; 1994. p. 223-243.

14. Adler-Nissen. Enzymatic hydrolysis of food proteins. New York, USA: Elsevier applied science publishers LTD; 1986. p. 365-404.

15. Owens JD, Mendoza LS. Enzymatically hydrolysed and Loctenially fermented fishery products. Food Technol. 1985;20:273.

16. Fischer W, Bianchi G. FAO Identification sheets for fishery purpose. Western India Ocean: Fishing area 51. Marine Resources service fishery Resources and Environment Division FAO Fisheries department Rome Italy; 1984.

17. Halldorsdottir SM, Kristinsson HG, Sveinsdottir H, et al. The effect of natural antioxidants on haemoglobin-mediated lipid oxidation during enzymatic hydrolysis of cod protein. Food Chem. 2013;141(2):914-919

18. AOAC. Official Methods of Analysis. In: Gaithersburg MD. 18th ed. Maryland, USA: Association of Official Analytical Chemists; 2000.

19. Weaver CM, Daniel JR. The Food Chemistry Laboratory: A Manual for Experimental Foods, Dietetics, and Food Scientists. 2nd ed. Boca Raton, USA: CRC Press; 2003. 152 p.

20. Snedecor GW, Cochran WG. Statistical methods. Calcutta, India: Oxford and IBH Public Conicle; 1962. 564 p.

21. Oramadike CE. Proximate Composition and Technological Properties of Wild African Catfish Chrysichthysnigrodigitatus (Lacépède1802). American Journal of Agricultural Science. 2015;2(2):54-58.

22. Hsu K. Purification of antioxidative peptides prepared from enzymatic hydrolysates of tuna dark muscle by-product. Food Chem. 2010;122:4248.

23. Thnkamma RK, Gopakumar A, Lekshmy Nair A, et al. Protein hydrolysate from miscellanoues fish. Fishery Technology. 1979;16(2):71-75.

24. Nair A Lekshmy, Gopakumar K. Soluble Protein Isolates from Low Cost Fish and fish wastes. Fish Technol. 1982;19:101-103.

25. Sugiyama KM, Egawa K, Takada H, et al. Nutritive evaluation of fish protein hydrolysate Ibid. 1991;44(1):13.

26. Normah I, Jamilah B, Saari N, et al. Optimization of hydrolysis conditions for the production of threadfin bream (Nemipterusjaponicus) hydrolysate by alcalase. Journal of Muscle Foods. 2005;16(2):87-102.

27. Sen DP, Sripathy P, Lahiry NL. Food Technology. 1962;16:138.

28. Bhaskar N, BenilaC, Radha G, et al. Optimization of enzymatic hydrolysis of visceral waste proteins of Catla (Catla catla) for preparing protein hydrolysate using a commercial protease. Bioresourc Technol. 2008;99(2):335-343.

29. Sripathy NL, Lahiry A, sreenivasan V, et al. Influence of degree of hydrolysis on nutritive value. Food Sci. 1963;28(3):365-369. 
30. Kristinsson HG, Rasco BA. Fish Protein hydrolysates: Production, biochemical, and functional properties. Crit Rev Food Sci Nutr. 2000;40(1):43-81

31. Chalamaiah M, Narsing Rao G, Rao DG, et al. Protein hydrolysates from meriga (Cirrhinusmrigala) egg and evaluation of their functional properties. Food Chemistry. 2010;120(3):652-657
32. Clinelle GV, dus CA. Lipid oxidation in food. In: AJ st Angelo (Ed.), USA: American chemical Society Washngton DC; 192. p. 279-289.

33. Martone CB, Borla OP, Sanchez JJ. Fishery by-product as a nutrient source for bacteria and archaea growth media. Bioresource Technology. $2005 ; 96(3): 383-387$ 